\title{
The Effect of Anxiety on Reading Comprehension among Distance EFL Learners
}

\author{
Manoochehr Jafarigohar \\ Payame Noor University, Tehran, Iran \\ Saeedeh Behrooznia (Corresponding author) \\ Islamic Azad University, Mashhad Branch, Iran \\ Tel: 98-915-507-8550Ｅ-mail: s_behrooznia2007@yahoo.com
}

$\begin{array}{lr}\text { Received: October 18, } 2011 & \text { Accepted: October 28, } 2011 \quad \text { Published: April 1, } 2012 \\ \text { doi:10.5539/ies.v5n2p159 } & \text { URL: http://dx.doi.org/10.5539/ies.v5n2p159 }\end{array}$

URL: http://dx.doi.org/10.5539/ies.v5n2p159

\begin{abstract}
This study investigated the correlation between the construct of Foreign Language Reading Anxiety (FLRA) and reading comprehension skill among Iranian distance EFL learners with age and gender serving as moderator variables. The research was carried out with a group of 112 male and female junior and senior students studying English at Mashhad Payame Noor University. A 33-item Likert-style Foreign Language Reading Anxiety Scale, a 28-item reading comprehension test, and a demographic questionnaire were completed by the participants. The Pearson product moment correlation, t-Test, and one-way ANOVA were used to analyze the data. The results indicated that there was a significant negative relationship between FLRA and reading comprehension; moreover, no such relationship was found between foreign language reading anxiety and age; and finally compared to males, females suffered more from anxiety.
\end{abstract}

Keywords: Age, Foreign language reading anxiety, Gender, Reading comprehension

\section{Introduction and Literature Review}

Anxiety is a part of human emotion which includes fear and uncertainty, uneasiness and frustration or tension (Brown, 2000; Sarason, 1988; Scovel, 1978; Spielberger, 1972). Vasa and Pine (2004) believe that the three basic interrelated aspects of anxiety are physiological, behavioral, and cognitive, but it is the cognitive aspect which has received the most attention in recent studies. Anxiety may be either facilitating; in a sense that it affects learning and performance positively or debilitating which hinders learning and performance (Alpert \& Haber, 1960). Facilitative anxiety stimulates the student to 'fight' the new learning task (Scovel, 1991), and debilitative anxiety, on the other hand, motivates the student to adopt avoidance behavior (Eysenck, 1979; Scovel, 1991).

Different types of anxiety are associated with different situations. They can be classified as Trait, State and Situation Anxiety. Trait anxiety is viewed as a "relatively stable personality characteristic" (Horwitz, 2001; Spielberger, 1983); whereas "state anxiety is seen as a response to a particular anxiety-provoking stimulus such as an important test" (Horwitz, 2001, p.113), or it is the real experience of anxiety and it can affect emotions, cognition, and behavior (MacIntyre, 1999). Trait anxiety is believed to "impair cognitive functioning to disrupt memory, to lead to avoidance behaviors, and to have several other effects" (Eysenck, 1979; in MacIntye \& Gardner, 1991c, p.87). Situation-specific anxiety is a new construct similar to trait anxiety but it is experienced in a single context or situation (MacIntyre, 1999). According to (MacIntye \& Gardner, 1991a) the most suitable measures for foreign language anxiety would be the situation-specific measures.

On the other hand, many foreign language learners experience foreign language (FL) anxiety which is "a situation-specific and unique type of anxiety closely related to the acquisition of a foreign language" (Horwitz et al., 1986, p. 125).

Although language anxiety can sometimes work as helpful "energizer" for L2 learning, the harmful effects of anxiety which is considered "debilitating anxiety" (Brown, 1994), cannot be easily ignored in the context of L2 teaching. Evidence of negative relations between anxiety and achievement has been studied in several researches to find the processes which are likely to be involved in such a negative relation (Blankstein, Toner \& Flett, 1989; Cassady \& Johnson, 2002; Hembree, 1988; Swain and Burnaby, 1976). Nevertheless, anxiety-provoking 
circumstances are part and parcel of teaching and specifically testing. Moreover, each second language learner might potentially suffer from a form of anxiety despite the age, gender, language experience, the form of language learning environment (EFL or ESL), and also pronunciation (Chao, 2003; Ortega, 2005;Pappamihiel, 2001; Tsai, 2003).

The prevalence of foreign language learning anxiety inspired Elaine Horwitz (1983 \& 1986) to develop the Foreign Language Classroom Anxiety Scale (FLCAS). This scale has served as the most widely used anxiety measure in foreign language learning researches including but not limited to chronologically-ordered studies by: Aida (1994); Rodriguez (1995); Oh (1996); Truitt (1997); Kuntz (1997); Yan (1998); Onwuegbuzie et al. (1999); Bailey et al. (1999); Spitalli (2000); and Coulombe (2000). Horwitz argues that although foreign language anxiety consists of three related anxieties (communication apprehension, test-anxiety, and fear of negative evaluation); it is more than the mere sum of its parts.

Moreover, it has been found that female learners are generically more worried and anxious than male learners in several studies which makes them to underachieve, to fail to consider themselves as capable, or to apply for senior positions, to confine their aspirations and even to be afraid of success (Chang, 1997; Daly, Felson \& Trudeau, 1991; Kreiser \& Rogharr, 1994; Onwuegbuzie, Bailey \& Daley, 1997). These findings are consistent with other studies which discovered that, generally, female learners are more concerned about language complications compared to male ones, and that they tend to be more anxious and worry-oriented than male students (Bernstein, Gierl \& Rogers, 1996; Garfinkel \& Hoberman, 1989; Padilla, Cervantes, Maldonado \& García 1988; Plancherel \& Bolognini, 1995).

\subsection{Anxieties of Different Language Contexts}

Since language anxiety is a situational specific construct, each language context may lead to a specific form of anxiety. Therefore, they can be classified into speaking anxiety, listening anxiety, writing anxiety, and reading anxiety. Nevertheless, the research on language anxiety has mainly studied oral aspects of language anxiety (speaking and listening), and relatively underestimating the other two components of language anxiety (reading and writing).

\subsection{Anxiety and L2 Reading}

By far, the number of research studies dealing with affect and L2 reading is limited. Reading in a foreign language ends in anxiety and finally poor language achievement "in conjunction of students' levels of reading anxiety and general foreign language anxiety" (Saito, Thomas, \& Horwitz, 1998, p. 202).

Saito, Horwitz, and Garza (1999) and Sellers (2000) found that reading anxiety is distinct from foreign language anxiety. Furthermore, Zhang (2000) and Adams (1996) believe that low language proficiency and teacher diversity may cause reading comprehension test anxiety.

\section{Statement of the problem and Significance of the study}

Except for the study of Hauck (2005), Harris (2003), Hurd (2000 \& 2002), Hurd et al. (2001), and White (1995, 1997, 1999), most explorations into language anxiety concentrate on classroom-based learning and there is little that particularly investigates anxiety in the distance learning context. To date, almost no attempt has been made to clarify the relationship between foreign language reading anxiety and reading comprehension, age and gender among distance EFL learners.

This study attempts to answer the following questions:

- Is there a relationship between foreign language reading anxiety and reading comprehension in distance education?

- Is there a relationship between foreign language reading anxiety and gender in distance education?

- Is there a relationship between foreign language reading anxiety and age in distance education?

\section{Methodology}

In order to estimate the reliability or internal consistency of the questionnaire, the researchers administered the questionnaire to a group of 18 students who were randomly selected from the original population of the EFL learners at Mashhad Payame Noor University (PNU).

By calculating the Cronbach's Alpha for the questionnaire, the FLRAS showed an internal consistency of 0.88 which is usually rated as a reliable index. Moreover, by applying the same formula for all the items when deleted, it became evident that all the items on the scale were considered reliable, except for item number 32 on the list which got the highest degree of reliability equal to 0.90 applying Cronbach's Alpha if the item was deleted.

As a result, this item (number 32) was omitted from the final administration of the scale and the final questionnaire 
consisted of 33 Likert-style items. (See Table 1 for the reliability of the items in the FLRAS and see Table 2 for the mean and standard deviation of each item).

\subsection{Participants}

The whole population of the study consisted of 542 Iranian learners studying English as a foreign language at B.A. level at Mashhad Payame Noor University in the first semester of 2007. These learners were all junior and senior students and comprised of both males and females.

In order to gain an accurate number of subjects to be included in the study through stratified random sampling, the researcher applied "Sample Population formula" for which the mean and standard deviation were not clear then. Accordingly to obtain the mean and standard deviation which were necessary for the "Sample Population formula" on the one hand, and substantiating the reliability of the questionnaire (FLRAS; adapted from FLCAS by Horwitz, Horwitz \& Cope, 1986) on the other hand, the researchers administered the questionnaire with a group of 18 students in the piloting phase of the study. (See Table 3 for the statistics related to sample population formula).

The final number of participants to be included in the research was 112 students, 71 females and 41 males. They ranged in age from 20 to 40 with the majority being between 20 and 28 .

\subsection{Materials}

For the present study the anxiety questionnaire was modified according to selected items from the Foreign Language Classroom Anxiety Scale (Horwitz, Horwitz, \& Cope, 1986). Items from the FLCAS were altered with a focus on L2 reading instead of general language learning and also a few items were added or changed to match the atmosphere and setting in distance education. (See the Appendix for a complete list of questions solicited on the written questionnaire).

\subsection{Procedure}

The study was carried out in several phases:

- In the first phase a demographic questionnaire was given to all of the 112 students. The questionnaire included questions about participant's age, gender, years of studying English and experience of traveling abroad.

- In the second phase, this group took a psychology test which was called Foreign Language Reading Anxiety Scale, adapted from FLCAS (Horwitz, Horwitz \& Cope, 1986). The scale consisted of 33 Likert-style questions (after calculating the internal consistency) with points ranging from Strongly Agree to Strongly Disagree.

- Finally, in the last phase of the study, the students were given a reading comprehension test consisting of 28 multiple-choice items based on 3 reading passages. This test was designed to examine the relationship between foreign language reading anxiety and reading comprehension on one hand and this newly-developed construct (FLRA) and age and gender on the other hand. For consistency reasons, all testing was conducted in the same condition and the procedures followed were the same during each administration.

\subsection{Analyses}

Data analysis for this study was carried out on the assumption that survey instruments were internally consistent and would produce valid data when used with EFL learners studying at Mashhad PNU. The analyses comprised of both descriptive and quantitative statistics.

The descriptive statistics calculated and summarized the frequencies, ranges, means and standard deviations for the FLRAS and Reading Comprehension Test scores besides the Individual Background Information Questionnaire concerning aspects related to age and gender of the participants.

And for quantitative analysis, SPSS (Statistical Package for Social Sciences) Version 10.0 was used. The statistical procedures included: Pearson product moment Correlation to examine the degree and the direction of the relationship between the independent variable (Foreign Language Reading Anxiety) and the dependent variable (Reading Comprehension Scores); T-test to compare the means of the males and females concerning Foreign Language Reading Anxiety and also to test the hypothesis concerning the relationship between FLRA and Gender; and finally one-way ANOVA to determine whether significant differences existed among different age groups of the participants.

\section{Results and Discussion}

\subsection{Descriptive Analysis}

As mentioned previously, the participant sample size, based on computing the sampling population formula, was 112 (See Table 4 and Figure 1 for sex information). 
Regarding the age of the participants of the study, they ranged from 20 to 40 which can be categorized on an interval scale of 20 to 24, 25 to 29, 30 to 34 and older than 34 and is reflected on a bar graph. (See Table 5 and Figure 2 for age information).

\subsection{FLRAS Scores}

The FLRAS was scored by assigning a value of one to five points to the chosen response. Responses indicating low-anxiety received one point, and those indicating high anxiety received five points. So the same procedure was followed for the items such as number 11, 15, 22, 24, 25, 26, 27, and 28 which were reverse-coded; consequently, the possible range of scores for the FLRAS is 33 to 165 . Scores from the administration of the FLRAS for this study ranged from 42 to 115 . The mean score was 79.18 and the standard deviation was 16.98 .

As pointed out previously, the FLRAS included 33 items, all of which can fit into different categories representing different dimensions of L2 reading and anxiety: general L2 reading; L2 reading tasks (oral and written) and L2 reading and fear of negative evaluation, then a few items referring to general L2 learning, besides 3 items regarding distance education setting. (Table 6 provides the means and standard deviations for all the questions and Table 7 lists descriptive statistics regarding the frequencies and percentages of students selecting each alternative).

\subsection{Research Hypothesis 1}

$\mathrm{H}_{1}$ : There is no significant relationship (either positive or negative) between foreign language reading anxiety and reading comprehension in distance education $(\mathrm{r}=0, \alpha<0.05)$.

The Pearson's product moment correlation was used to test the hypothesis. Since $\mathrm{r}^{\mathrm{obs}}<\mathrm{r}$ crit; $-0.211<0.026$, at $\alpha$ $<0.05$, the Null hypothesis $\left(\mathrm{HO}_{1}: \mathrm{r}=0\right.$, at $\left.\alpha<0.05\right)$ is rejected.

Therefore, the results can be said to be significant since there is only a $5 \%$ probability that robs $=-0.211$ occurred by chance alone, or a $95 \%$ probability that the observed correlation is due to other than chance factors. (See Table 8 and Figure 3 for the relationship between foreign language reading anxiety and reading comprehension scores).

It should be noted here that each point in the scatter plot represents a student's score. Therefore, the more tightly the points are clustered around the hypothetical straight line, the stronger the relationship between the two variables becomes, and in this study, since the relationship is rather weak, the line is inclined to a small degree.

\subsection{Research Hypothesis 2}

$\mathrm{HO}_{2}$ : There is no significant relationship between foreign language reading anxiety and gender in distance education $(\mathrm{r}=0, \alpha<0.05)$.

By computing T-test for both male and female groups, we reject the null hypothesis and accept the alternative hypothesis; since the observed $t$ is greater than the critical $t$ (tobs $>$ tcrit; $2.34>1.98$ ), we conclude that in this study, woman participants were significantly more anxious about reading foreign language than men participants (See Table 9 for the relationship between foreign language reading anxiety and gender).

\subsection{Research Hypothesis 3}

$\mathrm{HO}_{3}$ : There is no significant relationship between foreign language reading anxiety and age in distance education $(\mathrm{r}=0, \alpha<0.05)$.

The result of one-way ANOVA which is displayed in Table 5 shows that there is no significant difference among age groups with regard to foreign language reading anxiety; since F-ratio is smaller than $1(\mathrm{~F}=0.511, \alpha<0.05)$; consequently we accept the Null hypothesis and conclude that age doesn't have any significant effect on foreign language anxiety in distance education, and the observed differences were probably due to chance alone. (See Table 10 for relationship between foreign language reading anxiety and age).

\section{Conclusion}

\subsection{Pedagogical Implications}

A short review of the literature shows that not only is language anxiety a worldwide problem in language classes and mostly rooted in communication apprehension and test anxiety, but also much attention has been given to the affective state of each learner in ESL/EFL classes.

In order to overcome the negative and debilitative effects of anxiety on all the four skills particularly reading comprehension, it should be of utmost importance and high priority to teachers or instructors to remove any unnecessary anxiety from language learning, and create a stress-free, safe and relaxing atmosphere in the class where students feel secure, interested, joyful and motivated to learn and internalize the learning materials so that they can approach the aims of teaching and learning. Therefore, teachers play a prominent role in alleviating and 
controlling anxiety in the classroom. They are likely to facilitate language learning through providing a supportive and friendly environment, applying nonthreatening teaching methods and making use of interesting topics and themes which are relevant to the learner's lives and interests. Similarly, Rogers (1989) believes that "much of what is called learning... involves little feeling of personal meaning, and has insufficient relevance for the whole person, with a resulting lack of interest" (p. 99).

Brown (1994) maintains that instructors need to "establish interpersonal relationships" with their students (p. 201). Teachers should be warm and friendly in their relationships with students. Besides they should value effort, risk-taking and successful communication and also they should take it for granted that errors and mistakes are a natural part of learning. Consequently, in such an atmosphere students seek to have more opportunities to interact positively with each other and act in a cooperative rather than a competitive manner; as a result, they focus on communication rather than being worried and afraid of negative evaluation.

In conclusion, foreign language anxiety should be taken more seriously not only by instructors, but also by students and possibly program developers. This may be achieved through workshops or presentations on foreign language anxiety and exploring different possible ways to alleviate anxiety in the classroom. As Young (1999) believes the only way to train students to become better language learners is accomplished by helping students deal with and overcome their feelings of anxiety.

Moreover, one of the objectives of teacher training programs, or maybe in-services, should be to explore the possible ways of helping future teachers to use their personal experiences about the phenomenon of language learning to the benefit of their English language learners. Besides, future educators would take advantage of teacher education programs by being taught to identify the importance of the role of affect in language learning and how to operate to reduce its negative effect on the learning process, and achieve an ideal result. It is essential that teachers become familiar with the FLCAS instrument (Horwitz, Horwitz \& Cope, 1986) to increase awareness of foreign language anxiety and to be informed about different ways in which students experience it.

It should be also a main concern for the teacher to ensure that the levels of anxiety do not hamper the class progress. As MacIntyre and Gardner (1989) maintains that students feel anxious only after on-going negative experiences in the language learning environment.

Furthermore, the findings of this research are consistent with those of other studies: the female learners are more concerned about language difficulties than males, and women tend to be more anxious and worry-oriented than men. Nevertheless, in co-education systems where men and women study in the same class, there seems to be more peer-related anxiety. As Bracken and Crain (1994) state adolescence is a time for fluctuating interpersonal relationships; so that, peers become more important than teachers, and since girls depend more on their peers and social communication with them (Plancherel \& Bolognini, 1995) on the one hand, and they are afraid of being laughed at or cajoled by their peers on the other hand, they feel more anxious when they take a test or asked to answer a question in class.

Consequently, if teachers encourage more cooperative learning atmosphere in which the affective safety of all the participants is considered, students will have more opportunities to interact positively with each other and, as a result, anxiety would be reduced. While accepting that a little anxiety can be considered as a motivating factor, it is important for teachers to be trained on how to adjust the dose.

\section{References}

Adams, J. F. (1996). Help for anxiety and control issues: For reading anxiety, PTSD, borderline and narcissistic personality disorders and panic and anxiety attacks. [Online] Available: http://www.proportionalreading.com/anxiety.html

Aida, Y. (1994). Examination of Horwitz, Horwitz, and Cope's construct of foreign language anxiety: The case of students of Japanese. The Modern Language Journal, 78, 155-168.

Alpert, R., \& Haber, R. N. (1960). Anxiety in academic achievement situations. Journal of Abnormal Social psychology, 61(2), 207-215. http://dx.doi.org/10.1037/h0045464

Bailey, P., Daley, C. E., \& Onwuegbuzie, A. J. (1999). Foreign language anxiety and learning style. Foreign Language Annals, 32(1), 63-76. http://dx.doi.org/10.1111/j.1944-9720.1999.tb02376.x

Bernstein, G. A., Garfinkel, B. D., \& Hoberman, H. M. (1989). Self-reported anxiety in adolescents. American Journal of Psychiatry, 146 (3), 384-386.

Blankstein, K.R., Toner, B.B., \& Flett, G.L. (1989). Test anxiety and the contents of consciousness: Thought-listing and endorsement measures. Journal of Research in Personality, 23, 269-289. 
http://dx.doi.org/10.1016/0092-6566(89)90001-9

Bracken, B. A., \& Crain, R. M. (1994). Children's and adolescents' interpersonal relations: Do age, race, and gender define normalcy? Journal of Psychoeducational Assessment, 12 (1), 14-32.

Brown, H. D. (1994). Principles of language learning and teaching (3rd ed.). Englewood Cliffs, NJ: Prentice Hall.

Brown, H. D. (2000). Principles of language learning and teaching (4th ed.). White Plains, NY: Longman.

Cassady, J. C., \& Johnson, R. L. (2002). Cognitive test anxiety and academic performance. Contemporary Educational Psychology, 27, 270-295. http://dx.doi.org/10.1006/ceps.2001.1094

Chang, J. I. (1997, November). Contexts of adolescent worries: Impacts of ethnicity, gender, family structure, and socioeconomic status. Paper presented at the annual meeting of NCFR Fatherhood and Motherhood in a Diverse and Changing World, Arlington, VA.

Chao, C. T. (2003). Foreign language anxiety and emotional intelligence: A study of EFL students in Taiwan. Unpublished doctoral dissertation, Texas A\&M University-Kingsville.

Coulombe, D. (2000). Anxiety and beliefs of French-as-a-second-language learners at the university level. Unpublished doctoral dissertation, University of Laval, Quebec, Canada.

Daly, J. A., Kreiser, P. O., \& Rogharr, L. A. (1994). Question-asking comfort: Explorations of the demography of communication in the eighthgrade classroom. Communication Education, 43, 27-41.

Eysenck, M. W. (1979). Anxiety, learning and memory: A reconceptualization. Journal of Research in Personality, 13, 363-385. http://dx.doi.org/10.1016/0092-6566(79)90001-1

Felson, R. B., \& Trudeau, L. (1991). Gender differences in mathematics performance. Social Psychology Quarterly, 54, (2) 113-126. http://dx.doi.org/10.2307/2786930

Gierl, M. J., \& Rogers, W. T. (1996). A confirmatory factor analysis of the test anxiety inventory using Canadian high school students. Educational and Psychological Measurement, 56 (2), 315-324. http://dx.doi.org/10.1177/0013164496056002012

Harris, V. (2003). Adapting classroom-based strategy instruction to a distance learning context. TESL-EJ, 7(2), 1-19.

Hauck, M. (2005). Metacognitive Knowledge, Metacognitive Strategies, and CALL. In J. Egbert \& G. Petrie (Eds.), Call: Research Perspectives (pp. 65-86). New Jersey: Lawrence Erlbaum.

Hembree, R. (1988). Correlates, causes, effects, and treatment of test anxiety. Review of Educational Research, 58, 47-77. http://dx.doi.org/10.2307/1170348

Horwitz, E. K. (2001). Language anxiety and achievement. Annual Review of Applied Linguistics, 21(1), 112-126. http://dx.doi.org/10.1017/S0267190501000071

Horwitz, E. K., Horwitz, M. B., \& Cope, J. (1986). Foreign language classroom anxiety. The Modern Language Journal, 70(2), 125-132. http://dx.doi.org/10.2307/327317

Horwitz, E.K. (1983). Foreign language classroom anxiety scale. Unpublished manuscript.

Horwitz, E.K. (1986). Preliminary evidence for the reliability and validity of a foreign language anxiety scale. TESOL Quarterly, 20, 559-562. http://dx.doi.org/10.2307/3586302

Hurd, S. (2000a). Helping learners to help themselves: the role of metacognitive skills and strategies in independent language learning. In M. Fay \& D. Ferney (Eds.), Current trends in modern languages provision for non-specialist linguists (pp. 36-52). London: CILT.

Hurd, S. (2002). Taking account of individual learner differences in the planning and delivery of language courses for open, distance and independent learning. In Web conference proceedings 2002. London: CILT. [Online] Available: http://www.lang.ltsn.ac.uk/resources/conferenceitem.aspx?resourceid=1315

Hurd, S., Beaven, T., \& Ortega, A. (2001). Developing autonomy in a distance language learning context: issues and dilemmas for course writers. System, 29, 341- 355. http://dx.doi.org/10.1016/S0346-251X(01)00040-9

Kuntz, P. (1997). University students' beliefs about foreign language learning, with a focus on Arabic and Swahili at U.S.HEA Title VI African Studies Centers. Unpublished doctoral dissertation, University of Wisconsin, Madison.

MacIntyre, P. D., \& Gardner R. C. (1991a). Methods and results in the study of anxiety and language learning: A review of the literature. Language Learning, 41(1), 85-117. http://dx.doi.org/10.1111/j.1467-1770.1991.tb00677.x

MacIntyre, P. D. (1999). Language anxiety: a review of the research for language teachers. In Young, D. (Ed.) Affect 
in foreign language and second language learning: a practical guide to creating a low-anxiety classroom atmosphere (pp. 24-45). Boston, MA: McGraw-Hill.

MacIntyre, P. D., \& Gardner, R. C. (1989). Anxiety and second language learning: Toward a theoretical clarification. Language Learning, 39 (2), 251-275. http://dx.doi.org/10.1111/j.1467-1770.1989.tb00423.x

MacIntyre, P. D., \& Gardner, R. C. (1991c). Language anxiety: its relationship to other anxieties and to processing in native and second languages. Language Learning, 41, 87, 513-534. http://dx.doi.org/10.1111/j.1467-1770.1991.tb00691.x

Oh, M.T. (1996). Beliefs about language learning and foreign language anxiety: A study of American university students learning Japanese. Dissertation Abstracts International, 57 (9), 3858A. (UMI No.9705927).

Onwuegbuzie A. J., Bailey P., \& Daley C. E. (1999a). Relationships between anxiety and achievement at three stages of learning a foreign language. Perceptual and Motors Skills, 88, 1085-1093. http://dx.doi.org/10.2466/PMS.88.3.1085-1093

Onwuegbuzie, A. J., Bailey, P., \& Daley, C. E. (1997, November). Foreign language anxiety among college students. Paper presented at the annual meeting of the Mid-South Educational Research Association, Memphis, TN.

Ortega, A. M. C. (2005). Measuring language anxiety perceived by Spanish university students of English. [Online] Available: http://www.publicacions.ub.es/revistes/bells12/articulos.asp?codart=102

Padilla, A. M., Cervantes, R. C., Maldonado, M., \& García, R. E. (1988). Coping responses to psychosocial stressors among Mexican and Central American immigrants. Journal of Community Psychology, 16 (4), 418-427. http://dx.doi.org/10.1002/1520-6629(198810)16:4<418::AID-JCOP2290160407>3.0.CO;2-R

Pappamihiel, N. E. (2001). Moving from the ESL classroom into the mainstream: An investigation of English language anxiety in Mexican girls. Bilingual Research Journal, 25, (1\&2), 1-8, 31-39. http://dx.doi.org/10.1080/15235882.2001.10162783

Plancherel, B., \& Bolognini, N. (1995). Coping and mental health in early adolescence. Journal of Adololescence, 18 (4), 459-474. http://dx.doi.org/10.1006/jado.1995.1033

Rodriguez, M. (1995). Foreign language classroom anxiety and students' success in EFL classes. Revista Venezolana de Linguistica Aplicada, 1, 23-32.

Rogers, C. R. (1989). The necessary and sufficient conditions of therapeutic personality change. In $\mathrm{H}$. Kirschenbaum \& V. L. Henderson (Eds.), The Carl Rogers reader (pp. 219-235). Boston: Houghton Mifflin. http://dx.doi.org/10.1037//0022-006X.60.6.827 and http://dx.doi.org/10.1037/0022-006X.60.6.827

Saito, Y., Horwitz, E. K., \& Garza (1999). Foreign language reading anxiety. The Modern Language Journal, 83, 202-218. http://dx.doi.org/10.1111/0026-7902.00016

Saito, Y., Thomas, G. J., \& Horwitz, E. K. (1998). Foreign Language Reading Anxiety. The Modern Language Journal, 83(2), 202-218. http://dx.doi.org/10.1111/0026-7902.00016

Sarason, I. G. (1988). Anxiety, self-preoccupation and attention. Anxiety Research, 1, 3-7. http://dx.doi.org/10.1080/10615808808248215

Scovel, T. (1978). The effect of affect on foreign language learning: A review of the anxiety research. Language Learning, 28(1), 129-142. http://dx.doi.org/10.1111/j.1467-1770.1978.tb00309.x

Scovel, T. (1991). The effect of affect on foreign language learning: A review of the anxiety research. In E. K. Horwitz \& D. J. Young (Eds.), Language anxiety: From theory and research to classroom implications (pp. 15-23). Englewood Cliffs, NJ: Prentice Hall. http://dx.doi.org/10.1111/j.1467-1770.1978.tb00309.x

Sellars, V. (2000). Anxiety and reading comprehension in Spanish as a foreign language. Foreign Language Annals, 33(5), 512-521. http://dx.doi.org/10.1111/j.1944-9720.2000.tb01995.x

Spielberger, C. D. (1972). Anxiety: Current trends in theory and research. New York: Academic Press.

Spielberger, C. D. (1983). Manual for the state-trait Anxiety Inventory (Form Y). Palo Alto, CA: Consulting Psychologists Press.

Spitalli, E.J. (2000). The relationship between foreign language anxiety and attitudes toward multiculturalism in high-school students. Unpublished master's thesis, Benedictine University, Lisle, IL.

Swain, M., \& Burnaby, B. (1976). Personality characteristics and second language learning in young children: A pilot study. Working Papers in Bilingualism, 11, 115-128. 
Truitt, S. N. (1997). Anxiety and Beliefs About Language Learning: A Study of Korean Universitv Students Learning English. Unpublished doctoral dissertation. The University of Texas, Austin.

Tsai, C. I. (2003). Anxiety and beliefs about second language learning. Unpublished doctoral dissertation. Texas A\&M University-Kingsville.

Vasa, R. A., \& Pine, D. S. (2004). Neurobiology in anxiety disorders in children and adolescents. In T. R. Morris \& J. S. March (Eds), Anxiety disorders in children and adolescents. (pp. 3-26). New York: Guilford Press.

White, C. J. (1995). Autonomy and strategy use in distance foreign language learning. System, 23(2), 207-221. http://dx.doi.org/10.1016/0346-251X(95)00009-9

White, C. J. (1997). Effects of mode of study on foreign language learning. Distance Education, 18(1), 178-196. http://dx.doi.org/10.1080/0158791970180112

White, C. J. (1999). Expectations and emergent beliefs of self-instructed language learners. System, 27, 443-457. http://dx.doi.org/10.1016/S0346-251X(99)00044-5

Yan, X. (1998). An examination of foreign language classroom anxiety: Its sources and effects in a college English program in China. Unpublished doctoral dissertation. The University of Texas, Austin.

Young, D. J. (1999). Giving priority to the language learner first. In D. J. Young (Ed.), Affect in foreign language and second language learning: A practical guide to creating a low-anxiety classroom atmosphere (pp. 241-247). Boston: McGraw-Hill.

Zhang, L. J. (2000, December). Uncovering Chinese ESL students' reading anxiety in a study abroad context. Asian Pacific Journal of Language in Education, 3 (2), 31-52.

\section{Authors}

Manoochehr Jafarigohar: Ph.D. in TEFL, MA in TEFL, BA in English translation; head of PNU central library; author of thirteen academic textbooks; presentation in more than 20 international conferences; published papers in journals; 15 years experience of teaching English; 20 years of teaching and research in distance education.

Saeedeh Behrooznia (Corresponding author) is a teacher of TEFL at Islamic Azad University and Imamreza International University. She has been teaching English at various levels of ability for all age groups for 17 years at different institutes of Mashhad. She is an M.A. holder in TEFL. Her areas of interest include reading, gender studies in TEFL, psycholinguistics, and computer-assisted language learning. Her articles have been accepted and presented at different international conferences. 
Table 1. Reliability of FLRAS's Items

\begin{tabular}{|r|c|}
\hline Cronbach's Alpha & N of Items \\
\hline 0.887 & 34 \\
\hline
\end{tabular}

\begin{tabular}{|c|c|c|c|c|}
\hline Question & $\begin{array}{l}\text { Scale mean if } \\
\text { Item Deleted }\end{array}$ & $\begin{array}{l}\text { Scale Variance if Item } \\
\text { Deleted }\end{array}$ & $\begin{array}{l}\text { Corrected Item-Total } \\
\text { Correlation }\end{array}$ & $\begin{array}{l}\text { Cronbach's Alpha } \\
\text { if Item Deleted }\end{array}$ \\
\hline$\overline{\mathrm{Q} 1}$ & 74.89 & 287.987 & .682 & .880 \\
\hline Q2 & 74.39 & 284.840 & .588 & .880 \\
\hline Q3 & 74.61 & 285.663 & .529 & .881 \\
\hline Q4 & 74.44 & 274.850 & .787 & .876 \\
\hline$\overline{\mathrm{Q} 5}$ & 74.78 & 283.712 & .803 & .878 \\
\hline Q6 & 74.39 & 280.722 & .664 & .879 \\
\hline Q7 & 74.11 & 288.693 & .530 & .882 \\
\hline Q8 & 74.56 & 286.967 & .618 & .880 \\
\hline Q9 & 74.89 & 288.222 & .728 & .879 \\
\hline Q10 & 73.56 & 304.379 & .137 & .889 \\
\hline Q11 & 74.44 & 301.085 & .267 & .886 \\
\hline Q12 & 74.72 & 287.389 & .587 & .881 \\
\hline Q13 & 74.61 & 284.252 & .612 & .880 \\
\hline Q14 & 74.17 & 280.971 & .622 & .879 \\
\hline Q15 & 74.78 & 292.418 & .493 & .883 \\
\hline Q16 & 74.56 & 293.438 & .436 & .884 \\
\hline Q17 & 74.67 & 294.588 & .426 & .884 \\
\hline Q18 & 74.83 & 294.029 & .389 & .884 \\
\hline Q19 & 74.56 & 286.497 & .544 & .881 \\
\hline Q20 & 74.17 & 285.324 & .521 & .882 \\
\hline$\overline{\mathrm{Q} 21}$ & 74.50 & 314.735 & -.143 & .893 \\
\hline Q22 & 74.94 & 293.467 & .413 & .884 \\
\hline Q23 & 74.28 & 282.801 & .605 & .880 \\
\hline Q24 & 73.11 & 312.105 & -.069 & .891 \\
\hline Q25 & 74.17 & 280.147 & .725 & .878 \\
\hline Q26 & 74.00 & 287.412 & .519 & .882 \\
\hline Q27 & 74.94 & 294.291 & .391 & .884 \\
\hline Q28 & 74.28 & 319.271 & -.234 & .896 \\
\hline Q29 & 74.33 & 302.235 & .171 & .889 \\
\hline Q30 & 74.94 & 290.408 & .770 & .880 \\
\hline Q31 & 74.22 & 298.771 & .267 & .887 \\
\hline Q32 & 73.39 & 332.605 & -.506 & .902 \\
\hline Q33 & 74.67 & 301.882 & .234 & .887 \\
\hline Q34 & 74.11 & 309.634 & .007 & .890 \\
\hline
\end{tabular}


Table 2. The Mean and SD of the FLRAS' Items

\begin{tabular}{|c|c|c|c|}
\hline Question & $\mathrm{N}$ & Mean & Std.Deviation \\
\hline Q1 & 18 & 1.78 & 0.943 \\
\hline Q2 & 18 & 2.28 & 1.227 \\
\hline Q3 & 18 & 2.06 & 1.305 \\
\hline Q4 & 18 & 2.22 & 1.309 \\
\hline Q5 & 18 & 1.89 & 0.963 \\
\hline Q6 & 18 & 2.28 & 1.274 \\
\hline Q7 & 18 & 2.56 & 1.149 \\
\hline Q8 & 18 & 2.11 & 1.079 \\
\hline Q9 & 18 & 1.78 & 0.878 \\
\hline Q10 & 18 & 3.11 & 1.079 \\
\hline Q11 & 18 & 2.22 & 0.943 \\
\hline Q12 & 18 & 1.94 & 1.110 \\
\hline Q13 & 18 & 2.06 & 1.211 \\
\hline Q14 & 18 & 2.50 & 1.339 \\
\hline Q15 & 18 & 1.89 & 1.023 \\
\hline Q16 & 18 & 2.11 & 1.079 \\
\hline Q17 & 18 & 2.00 & 1.029 \\
\hline Q18 & 18 & 1.83 & 1.150 \\
\hline Q19 & 18 & 2.11 & 1.231 \\
\hline Q20 & 18 & 2.50 & 1.339 \\
\hline Q21 & 18 & 2.17 & 0.985 \\
\hline Q22 & 18 & 1.72 & 1.127 \\
\hline Q23 & 18 & 2.39 & 1.290 \\
\hline Q24 & 18 & 3.56 & 0.922 \\
\hline Q25 & 18 & 2.50 & 1.200 \\
\hline Q26 & 18 & 2.67 & 1.237 \\
\hline Q27 & 18 & 1.72 & 1.127 \\
\hline Q28 & 18 & 2.39 & 1.195 \\
\hline Q29 & 18 & 2.33 & 1.188 \\
\hline Q30 & 18 & 1.72 & 0.752 \\
\hline Q31 & 18 & 2.44 & 1.149 \\
\hline Q32 & 18 & 2.56 & 0.922 \\
\hline Q33 & 18 & 2.00 & 0.970 \\
\hline Q34 & 18 & 3.28 & 1.274 \\
\hline
\end{tabular}


Table 3. Statistics Related to Sample Population Formula

\begin{tabular}{|l|l|l|l|l|}
\hline Z(Standard score ) & mean & Standard deviation & Degree of freedom & Society population \\
\hline 1.96 & 71.39 & 21.546 & 0.05 & 542 \\
\hline
\end{tabular}

Table 4. Sex Information

\begin{tabular}{|l|l|l|l|l|}
\hline & Frequency & Percent & Valid Percent & Cumulative Percent \\
\hline Male & 41 & 36.6 & 36.6 & 36.6 \\
\hline Female & 71 & 63.4 & 63.4 & 100.0 \\
\hline Total & 112 & 100.0 & 100.0 & \\
\hline
\end{tabular}

Table 5. Age Information

\begin{tabular}{|l|l|l|l|l|}
\hline valid & Frequency & Percent & Valid Percent & Cumulative Percent \\
\hline 20 to 24 & 85 & 75.9 & 75.9 & 75.9 \\
\hline 25 to 29 & 15 & 13.4 & 13.4 & 89.3 \\
\hline 30 to 34 & 9 & 8.0 & 8.0 & 97.3 \\
\hline Upper than 34 & 3 & 2.7 & 2.7 & 100.0 \\
\hline Total & 112 & 100.0 & 100.0 & \\
\hline
\end{tabular}


Table 6. Statistics Related to Number, Mean and SD of Each Question

\begin{tabular}{|l|l|l|l|}
\hline Question & Number & Mean & Std. Deviation \\
\hline Q1 & 112 & 1.85 & 1.050 \\
\hline Q2 & 112 & 2.50 & 1.259 \\
\hline Q3 & 112 & 2.17 & 1.185 \\
\hline Q4 & 112 & 2.57 & 1.176 \\
\hline Q5 & 112 & 2.13 & 0.960 \\
\hline Q6 & 112 & 2.83 & 1.229 \\
\hline Q7 & 112 & 2.66 & 1.270 \\
\hline Q8 & 112 & 2.06 & 1.025 \\
\hline Q9 & 112 & 2.04 & 1.077 \\
\hline Q10 & 112 & 3.31 & 1.245 \\
\hline Q11 & 112 & 2.09 & 0.906 \\
\hline Q12 & 112 & 2.04 & 1.170 \\
\hline Q13 & 112 & 2.61 & 1.276 \\
\hline Q14 & 112 & 1.82 & 1.266 \\
\hline Q15 & 112 & 1.95 & 0.994 \\
\hline Q16 & 112 & 2.54 & 1.251 \\
\hline Q17 & 112 & 2.35 & 1.213 \\
\hline Q18 & 112 & 1.99 & 1.135 \\
\hline Q19 & 112 & 2.08 & 1.121 \\
\hline Q20 & 112 & 2.82 & 1.296 \\
\hline Q21 & 112 & 2.59 & 1.249 \\
\hline Q22 & 112 & 3.01 & 1.29 \\
\hline Q23 & 112 & 2.55 & 1.229 \\
\hline Q24 & 112 & 3.22 & 1.071 \\
\hline Q25 & 112 & 2.37 & 1.099 \\
\hline Q26 & 112 & 2.45 & 1.229 \\
\hline Q27 & 112 & 3.19 & 1.026 \\
\hline Q28 & 112 & 2.76 & 1.033 \\
\hline Q29 & 112 & 2.66 & 1.212 \\
\hline Q30 & 112 & 1.96 & 1.134 \\
\hline Q31 & 112 & 2.67 & 1.052 \\
\hline Q32 & 112 & 1.66 & 0.999 \\
\hline Q33 & 112 & 1.66 & 0.869 \\
\hline
\end{tabular}


Table 7. Statistics Related to Number and Percent of Each Chosen Alternative

\begin{tabular}{|c|c|c|c|c|c|c|c|c|c|c|}
\hline \multirow[b]{2}{*}{ Question } & \multicolumn{2}{|c|}{ Strongly Agree } & \multicolumn{2}{|c|}{ Agree } & \multicolumn{2}{|c|}{ No Comment } & \multicolumn{2}{|c|}{ Strongly Disagree } & \multicolumn{2}{|c|}{ Disagree } \\
\hline & 1 & $\mathrm{P}$ & 2 & $\mathrm{P}$ & 3 & $\mathrm{P}$ & 4 & $\mathrm{P}$ & 5 & $\mathrm{P}$ \\
\hline Q1 & 55 & $49.1 \%$ & 33 & $29.5 \%$ & 12 & $10.7 \%$ & 14 & $8.9 \%$ & 2 & $1.8 \%$ \\
\hline Q2 & 29 & $25.9 \%$ & 36 & $32.1 \%$ & 16 & $14.3 \%$ & 24 & $21.4 \%$ & 7 & $6.3 \%$ \\
\hline Q3 & 42 & $37.5 \%$ & 35 & $31.3 \%$ & 11 & $9.8 \%$ & 22 & $19.6 \%$ & 2 & $1.8 \%$ \\
\hline $\mathrm{Q} 4$ & 22 & $19.6 \%$ & 40 & $35.7 \%$ & 19 & $17.0 \%$ & 26 & $23.2 \%$ & 5 & $4.5 \%$ \\
\hline Q5 & 37 & $33.0 \%$ & 32 & $28.6 \%$ & 35 & $31.3 \%$ & 8 & $7.1 \%$ & 0 & $0.0 \%$ \\
\hline Q6 & 21 & $18.8 \%$ & 25 & $22.3 \%$ & 25 & $22.3 \%$ & 34 & $30.4 \%$ & 7 & $6.3 \%$ \\
\hline$\overline{Q 7}$ & 24 & $21.4 \%$ & 36 & $32.1 \%$ & 13 & $11.6 \%$ & 32 & $28.6 \%$ & 7 & $6.3 \%$ \\
\hline Q8 & 37 & $33.0 \%$ & 48 & $42.9 \%$ & 11 & $9.8 \%$ & 15 & $13.4 \%$ & 1 & $0.9 \%$ \\
\hline$\overline{\text { Q9 }}$ & 42 & $37.5 \%$ & 41 & $36.6 \%$ & 13 & $11.6 \%$ & 14 & $12.5 \%$ & 2 & $1.8 \%$ \\
\hline Q10 & 11 & $9.8 \%$ & 17 & $15.2 \%$ & 34 & $30.4 \%$ & 26 & $23.2 \%$ & 24 & $21.4 \%$ \\
\hline Q11 & 35 & $31.3 \%$ & 38 & $33.9 \%$ & 33 & $29.5 \%$ & 6 & $5.4 \%$ & 0 & $0.0 \%$ \\
\hline Q12 & 49 & $43.8 \%$ & 33 & $29.5 \%$ & 9 & $8.0 \%$ & 19 & $17.0 \%$ & 2 & $1.8 \%$ \\
\hline Q13 & 29 & $25.9 \%$ & 28 & $25.0 \%$ & 19 & $17.0 \%$ & 30 & $26.8 \%$ & 6 & $5.4 \%$ \\
\hline Q14 & 8 & $7.1 \%$ & 48 & $42.9 \%$ & 12 & $10.8 \%$ & 26 & $23.2 \%$ & 18 & $16.1 \%$ \\
\hline Q15 & 1 & $0.9 \%$ & 6 & $5.4 \%$ & 28 & $25.0 \%$ & 28 & $25.0 \%$ & 49 & $43.8 \%$ \\
\hline Q16 & 25 & $22.3 \%$ & 39 & $34.8 \%$ & 20 & $17.9 \%$ & 18 & $16.1 \%$ & 10 & $8.9 \%$ \\
\hline Q17 & 32 & $28.6 \%$ & 37 & $33.0 \%$ & 24 & $21.4 \%$ & 10 & $8.9 \%$ & 9 & $8.0 \%$ \\
\hline Q18 & 49 & $43.8 \%$ & 33 & $29.5 \%$ & 17 & $15.2 \%$ & 8 & $7.1 \%$ & 5 & $4.5 \%$ \\
\hline Q19 & 44 & $39.3 \%$ & 34 & $30.4 \%$ & 20 & $17.9 \%$ & 10 & $8.9 \%$ & 4 & $3.6 \%$ \\
\hline Q20 & 22 & $19.6 \%$ & 29 & $25.9 \%$ & 17 & $15.2 \%$ & 33 & $29.5 \%$ & 10 & $8.9 \%$ \\
\hline Q21 & 31 & $27.7 \%$ & 18 & $16.1 \%$ & 36 & $32.1 \%$ & 18 & $16.1 \%$ & 8 & $7.1 \%$ \\
\hline Q22 & 58 & $51.8 \%$ & 6 & $5.4 \%$ & 5 & $4.5 \%$ & 39 & $34.8 \%$ & 3 & $2.7 \%$ \\
\hline Q23 & 26 & $23.2 \%$ & 36 & $32.1 \%$ & 17 & $15.2 \%$ & 26 & $23.2 \%$ & 6 & $5.4 \%$ \\
\hline Q24 & 7 & $6.3 \%$ & 16 & $14.3 \%$ & 50 & $44.6 \%$ & 21 & $18.8 \%$ & 17 & $15.2 \%$ \\
\hline Q25 & 29 & $25.9 \%$ & 36 & $32.1 \%$ & 24 & $21.4 \%$ & 19 & $17.0 \%$ & 2 & $1.8 \%$ \\
\hline Q26 & 32 & $28.6 \%$ & 29 & $25.9 \%$ & 25 & $22.3 \%$ & 17 & $15.2 \%$ & 7 & $6.3 \%$ \\
\hline Q27 & 57 & 50.9 & 35 & $31.3 \%$ & 8 & $7.1 \%$ & 7 & $6.3 \%$ & 3 & $2.7 \%$ \\
\hline Q28 & 13 & $11.6 \%$ & 30 & $26.8 \%$ & 45 & $40.2 \%$ & 15 & $13.4 \%$ & 7 & $6.3 \%$ \\
\hline Q29 & 23 & $20.5 \%$ & 32 & $28.6 \%$ & 21 & $18.8 \%$ & 28 & $25.0 \%$ & 6 & $5.4 \%$ \\
\hline Q30 & 50 & $44.6 \%$ & 35 & $31.3 \%$ & 13 & $11.6 \%$ & 6 & $5.4 \%$ & 6 & $5.4 \%$ \\
\hline Q31 & 18 & $16.1 \%$ & 29 & $25.9 \%$ & 38 & $33.9 \%$ & 22 & $19.6 \%$ & 3 & $2.7 \%$ \\
\hline Q32 & 15 & $13.4 \%$ & 50 & $44.6 \%$ & 5 & $4.5 \%$ & 33 & $29.5 \%$ & 9 & $8.0 \%$ \\
\hline Q33 & 27 & $24.1 \%$ & 28 & $25.0 \%$ & 42 & $37.5 \%$ & 12 & $10.7 \%$ & 1 & $0.9 \%$ \\
\hline
\end{tabular}


Table 8. The Correlation between FLRA and Reading Comprehension Scores

\begin{tabular}{|ll|l|l|}
\hline & & Exam & $\mathrm{Q}$ \\
\hline Exam & Pearson Correlation & 1 & -.211 \\
& Sig. (2- tailed) & & .026 \\
& $\mathrm{~N}$ & 112 & 112 \\
\hline $\mathrm{Q}$ & Pearson Correlation & -.211 & 1 \\
& Sig. (2- tailed) & .026 & \\
& $\mathrm{~N}$ & 112 & 112 \\
\hline
\end{tabular}

Note. Correlation significant at the 0.05 level (2-tailed).

Table 9. t-Test Results Concerning the Difference between Men and Women

\begin{tabular}{|l|l|l|l|l|l|l|l|}
\hline Gender & $\mathrm{N}$ & Percent & Mean & SD & t & df & t-critical value \\
\hline Male & 41 & 36.6 & 71.56 & 18.18 & 2.34 & 110 & 1.98 \\
\hline female & 71 & 63.4 & 82.00 & 14.44 & & & \\
\hline
\end{tabular}

Note. The result is significant at 0.05 level.

Table 10. One-way ANOVA Concerning the Relationship between FLRA \& Age

\begin{tabular}{|l|l|l|l|l|l|}
\hline & Sum of Squares & df & Mean Square & F & Sig. \\
\hline Between Groups & 447.651 & 3 & 149.217 & \multirow{3}{*}{0.511} & \multirow{2}{*}{0.676} \\
\cline { 1 - 4 } Within Groups & 31557.412 & 108 & 292.198 & & \\
\hline Total & 32005.063 & 111 & & \\
\hline
\end{tabular}




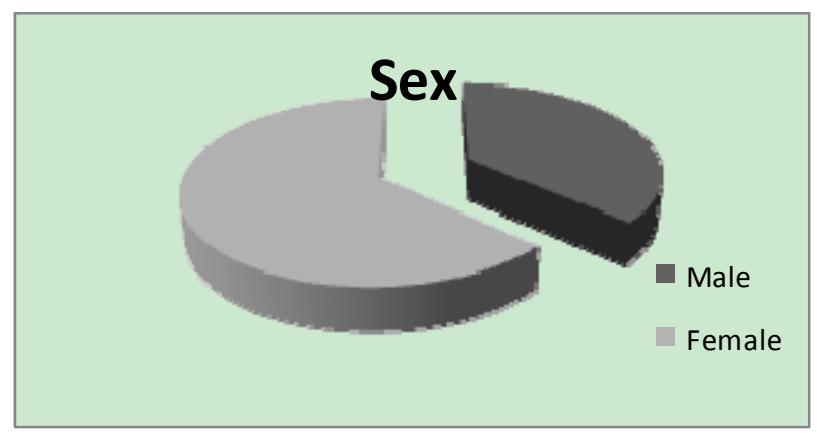

Figure 1. Circular Diagram of the Gender of the Population

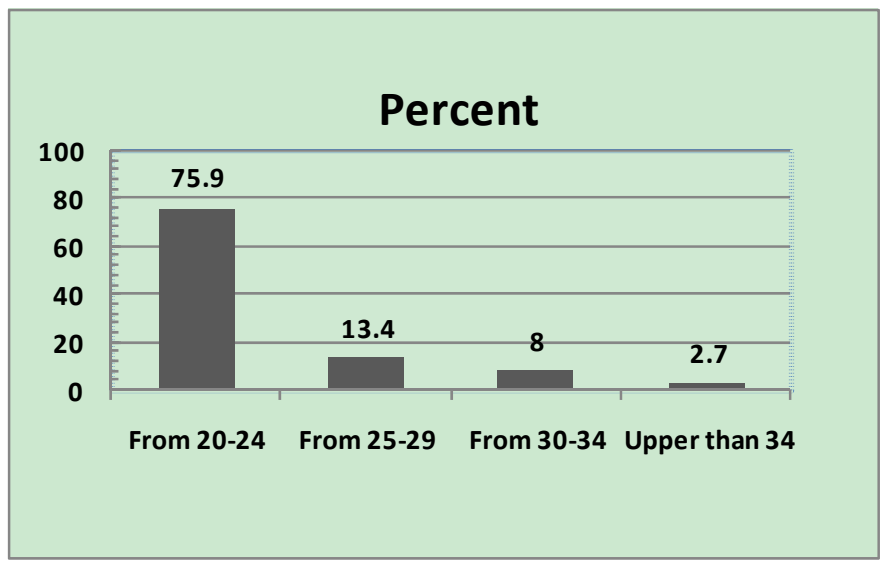

Figure 2. Bar Graph of the Age of the Participants

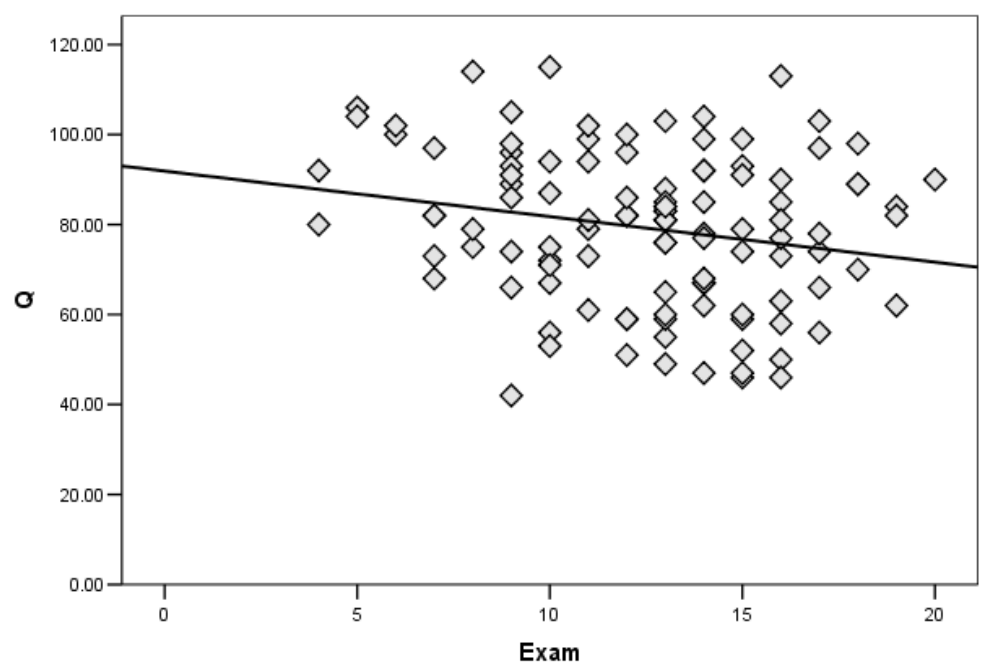

Figure 3. The Scatter Plot of the Relationship between FLRA Scores \& Reading Comprehension Scores 


\section{Appendix}

\section{Foreign Language Reading Anxiety Scale}

The following statements concern the situation of foreign language reading anxiety. There are no right or wrong answers. Please rate how much these statements reflect how you feel or think personally. Please select the choice corresponding to the degree of your agreement or disagreement.

1=Strongly Agree, $\quad 2=$ Agree,$\quad 3=$ No Comment $\quad 4=$ Strongly Disagree , 5= Disagree

\begin{tabular}{|c|c|c|c|c|c|}
\hline Statements & 1 & 2 & 3 & 4 & 5 \\
\hline 1. I become anxious when I should read in English outside of this course for homework. & & & & & \\
\hline 2. I become anxious when I have to read in English out loud in class. & & & & & \\
\hline 3. Generally speaking, I become anxious when I have to read English in class. & & & & & \\
\hline $\begin{array}{l}\text { 4. I become anxious when I have to answer questions orally in class about what I have read in } \\
\text { English. }\end{array}$ & & & & & \\
\hline $\begin{array}{l}\text { 5. I feel afraid when I have to read lengthy texts in English as homework in future English } \\
\text { courses. }\end{array}$ & & & & & \\
\hline 6. I fear not understanding the lengthy texts I will have to read in future English courses. & & & & & \\
\hline $\begin{array}{l}\text { 7. I become anxious when I am asked to write compositions in English about what I have read } \\
\text { in this class. }\end{array}$ & & & & & \\
\hline $\begin{array}{l}\text { 8. I become anxious when I have to answer the multiple choice questions about what I have } \\
\text { read in English. }\end{array}$ & & & & & \\
\hline 9. I would feel anxious while reading English in class. & & & & & \\
\hline 10. I would feel less nervous about reading English in front of others if I knew them. & & & & & \\
\hline 11. I feel very relaxed in English class when I have studied the scheduled learning contents. & & & & & \\
\hline $\begin{array}{l}\text { 12. I am anxious in class when I am the only person answering the question advanced by my } \\
\text { teacher in English class. }\end{array}$ & & & & & \\
\hline 13. I start to panic when I know I will be graded in English class. & & & & & \\
\hline 14. I fear giving a wrong answer while answering questions in English class. & & & & & \\
\hline 15. I enjoy English class when I know that we are going to read in English. & & & & & \\
\hline 16. I feel shy when I read in English on the stage in front of the class. & & & & & \\
\hline 17. When it comes to being corrected by my teacher, I am afraid of taking English class. & & & & & \\
\hline 18. I am so nervous that I tremble when I am going to attend the English written tests. & & & & & \\
\hline $\begin{array}{l}\text { 19. I get frustrated when I am asked to read with classmates in English in a short period of } \\
\text { time. }\end{array}$ & & & & & \\
\hline 20. I worry about the written test in English class. & & & & & \\
\hline 21. I would feel better about reading in English if the class were smaller. & & & & & \\
\hline 22. I feel relaxed in English class when I preview very well. & & & & & \\
\hline 23. I stumble when I answer questions in English. & & & & & \\
\hline 24. I like going to class when I know that written tasks are going to be performed. & & & & & \\
\hline $\begin{array}{l}\text { 25. I know that everyone makes mistakes while reading in English, so I am not afraid of } \\
\text { being laughed at by others. }\end{array}$ & & & & & \\
\hline 26. I like to volunteer answers in English class. & & & & & \\
\hline 27. I am more willing to get involved in class when the topics are interesting. & & & & & \\
\hline 28. I don't feel tense in written test if I get more practice reading in class. & & & & & \\
\hline 29. I feel pressure when my teacher corrects my written mistakes in class. & & & & & \\
\hline 30. Going to English reading class makes me more nervous than going to other classes. & & & & & \\
\hline 31. I feel anxious while doing reading tasks when there is no teacher to guide me. & & & & & \\
\hline $\begin{array}{l}\text { 32. I feel anxious because generally in distance education I feel unsure of myself and my } \\
\text { abilities. }\end{array}$ & & & & & \\
\hline $\begin{array}{l}\text { 33. I feel anxious because I am older than the other students in class and I feel unsure of my } \\
\text { learning abilities because of that matter. }\end{array}$ & & & & & \\
\hline
\end{tabular}

